\title{
Creatine supplementation: effects on blood creatine kinase activity responses to resistance exercise and creatine kinase activity measurement
}

\author{
Marco Machado", ${ }^{*}$ Rafael Pereira ${ }^{1}$, Felipe Sampaio-Jorge ${ }^{2}$, Franz Knifis ${ }^{3}$, Anthony Hackney ${ }^{4}$ \\ ${ }^{1}$ Laboratory of Physiology and Biokinetics, Iguaçu University, ${ }^{2}$ Laboratory of Biomechanics, ISE-CENSA, ${ }^{3}$ Universidade \\ Estácio de Sá, ${ }^{4}$ Applied Physiology Laboratory, University of North Carolina
}

\begin{abstract}
The purpose of this study was to determine the effects of creatine supplementation and exercise on the integrity of muscle fiber, as well as the effect of the supplementation on the creatine kinase (CK) assay measurement. Forty-nine sedentary individuals participated in a double-blind study and were divided into two groups: $\mathrm{C}(\mathrm{n}=26)$ received $4 \times 5$-day packages of $0.6 \mathrm{~g} \cdot \mathrm{kg}^{-1}$ of body weight contained $50 \%$ of creatine $+50 \%$ of dextrose, and $\mathrm{P}(\mathrm{n}=23)$ received packages containing only dextrose. On the first day the groups performed a 1RM test for bench press, seated row, leg extension, leg curl and leg press. On $\mathrm{D}_{7}$ they received the supplements. On the fourteenth day, they performed a training session of five exercises, each in three sets of ten repetitions at $75 \%$ of $1 \mathrm{RM}$. Blood was collected before $\left(\mathrm{D}_{14}\right)$ and after the exercise session $\left(\mathrm{D}_{15}\right)$. Differing levels of blood creatine were tested to determine the influence on the assay measurements of CK. ANOVA and Tukey's post-hoc tests were used to compare groups and different times of study protocol $(\mathrm{P}<0.05)$. No changes were observed in $\mathrm{CK}$ activity of the groups from $\mathrm{D}_{0}, \mathrm{D}_{7}$ and $\mathrm{D}_{14}$. On $\mathrm{D}_{15} \mathrm{CK}$ activity increases $140 \%$ (women) and $200 \%$ (men). There was no difference in $\mathrm{CK}$ activity between groups. Blood creatine levels up to $5 \mathrm{mM}$ produced no significant effect on CK assay results. CK activity increased after resistance exercise, while creatine supplementation produced no difference in the muscle cellular integrity nor compromised assay methodology.
\end{abstract}

Uniterms: Physical exercise/effects. Creatine/supplementation/effects. Creatine Kinase/assay. Muscle fibers.

O objetivo do presente estudo foi determinar o efeito da suplementação de creatina e do exercício na integridade das fibras musculares e, também, o efeito da suplementação na técnica de mensuração da atividade da creatina kinase (CK). Quarenta e nove sedentários participaram de um estudo duplo-cego e foram divididos em dois grupos: $\mathrm{C}(\mathrm{n}=26)$ que receberam $4 \mathrm{x} 5$ dias embalagens com $0,6 \mathrm{~g} \cdot \mathrm{kg}^{-1} \mathrm{de} \mathrm{massa}$ corporal com $50 \%$ de creatina $+50 \%$ de dextrose, e $\mathrm{P}(\mathrm{n}=23)$ que receberam embalagens contendo apenas dextrose. No primeiro dia, eles realizaram o teste de 1RM para os exercícios supino reto, remada sentada, cadeira extensora, mesa flexora, e leg press. No $\mathrm{D}_{7}$ receberam os suplementos. No décimo quarto dia eles realizaram uma sessão de treinos com os cinco exercícios, cada um com 3x10 repetições a 75\% de 1RM. Sangue foi coletado antes $\left(D_{14}\right)$ e depois da sessão de exercícios $\left(D_{15}\right)$. Diferentes concentrações de creatina no sangue foram testadas para determinar a influência nos métodos de medida da atividade de CK. ANOVA e o teste post-hoc de Tukey foram usados para comparar os grupos e as diferentes coletas $(\mathrm{P}<0,05)$. Não foram observadas mudanças significativas na atividade de $\mathrm{CK}$ nos grupos em $\mathrm{D}_{0}, \mathrm{D}_{7} \mathrm{e}$ $\mathrm{D}_{14}$. Em $\mathrm{D}_{15}$ a atividade de CK aumentou 140\% (mulheres) e 200\% (homens). Não houve diferenças na atividade de CK entre os grupos. Concentrações sanguíneas de creatina até $5 \mathrm{mM}$ não produziram efeitos significativos nos resultados de CK. A atividade de CK aumenta após o exercício, mas a creatina não tem influência na integridade da fibra muscular ou compromete o método de análise da CK.

Unitermos: Exercício físico/efeitos. Creatina/suplementação/efeitos. Creatina quinase/aividade. Fibras musculares.

\footnotetext{
*Correspondence: M. Machado. Laboratório de Fisiologia e Biocinética, Coordenação de Educação Física, Universidade Iguaçu - UNIG - Campus V, BR 356 - Km 02, 28.300-000 - Itaperuna - RJ, Brazil.

E-mail: marcomachado1@gmail.com
} 


\section{INTRODUCTION}

Physical strain and metabolic stress, caused by intense physical activities, may cause muscle injury to an overwhelming extent in sedentary individuals when they either begin or resume a physical activity program (Hootman et al., 2002). Muscle fiber disruption can result in the release of its intracellular content (Chen, Hsieh, 2002; Clarkson, Hubal, 2002; Nosaka et al., 2002; Tidball, 2005; Brancaccio et al., 2007).

By the end of the 1980's, some research studies substantiated that oral ingestion of creatine increased muscle concentrations of phosphocreatine. These findings led to an increased number of athletes using creatine supplementation in an attempt to boost their performance (Terjung et al., 2000; Lemon, 2002; Rawson, Persky, 2007). An enhancement in power, muscular strength, and both total and lean body mass was described in individuals who used creatine supplementation and played sports at a recreational level (Becque et al., 2000; Mihic et al., 2000). Despite the growing number of studies on this topic, much controversy remains over creatine use and its effects (Lemon, 2002; Kreider et al. 2003; Brudnak 2004; Dennehy et al., 2005).

It is suggested that phosphocreatine, due to its amphipathic nature, can bind to the plasma membrane thereby increasing its stability (Saks, Strumia 1993; Matthews et al., 1998). On the other hand, anecdotal evidence (coaching, personal training etc.) shows that the intracellular osmolarity increase, verified after creatine supplementation, could lead to muscle injuries during physical exercise. However, the experimental results are conflicting and there is no consensus on the relationship between creatine supplementation and the integrity of the muscle macrostructure (Rawson, Persky 2007; Rawson et al., 2007).

Proteins such as creatine kinase $(\mathrm{CK})$, lactate dehydrogenase (LDH) and myoglobin have been extensively used as markers for muscle micro-injuries (Stupka et al., 2000; Clarkson, Hubal, 2002; Phillips et al., 2003; Machado et al., 2009) including in creatine supplemented subjects (Mihic et al., 2000; Robinson et al., 2000; Rawson et al., 2001; Kreider et al., 2003; Rawson et al., 2007). Most of the studies using CK as a muscle injury marker do not measure serum creatine content, even those in which creatine was supplemented. This approach could lead to errors because the common measurement technique for $\mathrm{CK}$ in serum involves using enzymatic determination; i.e. the Oliver-Rosalki method (Rosalki, 1967) (see Figure 1). Specifically, CK activity is measured indirectly through the assessment of the variation in the Nicotinamide
Adenine Dinucleotide reduced (NADH) concentration in a coupled reaction (Figure 1). The clinical use of this method has become commonplace due to its low cost and reliability in the diagnosis of cardiac and skeletal muscle injuries. It has also been utilized in numerous exerciserelated studies, including those in which the individuals were subjected to creatine supplementation (Mihic et al., 2000; Robinson et al., 2000; Rawson et al., 2001; Kreider et al., 2003; Rawson et al., 2007).

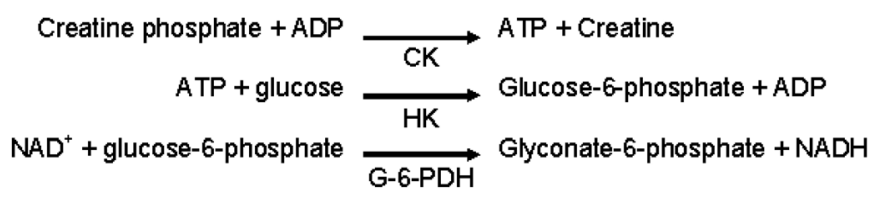

FIGURE 1 -Coupled enzymatic method used to measure the CK activity (Oliver-Rosalki method). NADH absorbance measured at $340 \mathrm{~nm}$ increases proportionally to the $\mathrm{CK}$ activity in the sample (HK) hexokinase; (G-6-PDH) Glucose-6-Phosphate Dehydrogenase.

In this study we attempted to determine whether creatine supplementation can protect against muscle injury in sedentary individuals after resistance exercise (i.e., maintain the integrity of muscle fibers, verified through blood CK activity); to compare the effects of gender; and more importantly, if plasma creatine concentrations attained after oral intake can affect CK activity measurement (i.e. methodology-technique).

\section{METHODS}

\section{Subjects}

Forty-nine sedentary individuals (men and eumenorrheic women), aged eighteen to twenty-five, who were neither drug nor nutritional supplement users, volunteered to participated in a randomized double-blind study. The subjects were divided according to a computer generated randomization list into two groups: Creatine $(\mathrm{C}, \mathrm{n}=26)$, and receiving other Placebo treatment $(P, n=23)$. Subjects' characteristics are displayed in Table I. The experimental conditions were in accordance with the norms of the Brazilian National Health Council, under Resolution No. 196, promulgated in October 1996, referring to scientific research on human subjects.

\section{Experimental procedure}

On the first day $\left(\mathrm{D}_{0}\right)$ the subjects were informed about the details of the experimental protocol. Subsequently, they were evaluated anthropometrically, performed a 
TABLE I - Subject characterization before the experiment (D0). Anthropometric measurements, nutritional assessment and performance profile (mean $\pm \mathrm{SD}$ ) were evaluated on first day $\left(\mathrm{D}_{0}\right)$ of the experimental protocol. No significant difference among the groups was present for any of the analyzed parameters. Abbreviations for dietary macro-nutrient intake are (PTN) protein; (CHO) carbohydrate; and (LIP) lipids, expressed as a percentage contribution of total caloric intake. The exercise profile was measured at one maximum repetition and described in arbitrary units (AU)

\begin{tabular}{lcc}
\hline Characteristics & \multicolumn{2}{c}{ Groups } \\
\cline { 2 - 3 } & $\mathrm{Cr}(\mathrm{n}=26)$ & $\mathrm{P}(\mathrm{n}=23)$ \\
\hline Age (years) & $21 \pm 2$ & $21 \pm 2$ \\
Weight $(\mathrm{kg})$ & $64.4 \pm 11.5$ & $64.5 \pm 13.2$ \\
Height $(\mathrm{cm})$ & $175.0 \pm 6.0$ & $176.1 \pm 9.5$ \\
\% PTN & $16 \pm 5$ & $16 \pm 3$ \\
\% CHO & $55 \pm 6$ & $54 \pm 10$ \\
\% LIP & $29 \pm 5$ & $30 \pm 8$ \\
Bench press (AU) & $103.3 \pm 7.6$ & $102.5 \pm 9.4$ \\
Seated row (AU) & $47.7 \pm 12.8$ & $54.6 \pm 5.2$ \\
Leg extension (AU) & $59.4 \pm 5.7$ & $61.9 \pm 5.9$ \\
Leg curl (AU) & $63.3 \pm 13.8$ & $52.8 \pm 11.5$ \\
Leg press (AU) & $114.8 \pm 10.0$ & $118.5 \pm 11.2$ \\
\hline
\end{tabular}

maximum repetition test (1RM) for bench press, seated row, leg extension, leg curl and leg press, and donated blood for a CK measurement. On the seventh protocol day $\left(D_{7}\right)$, the subjects donated blood for CK dosage and received the supplements $(\mathrm{C}$ or $\mathrm{P})$. Each individual received twenty supplemental packages at $0.6 \mathrm{~g} . \mathrm{kg}^{-1}$ of body weight to be taken in four daily doses over five consecutive days. Group $\mathrm{C}$ packages contained $50 \%$ of creatine $(\mathrm{Nu}-$ trisport-Brazil) and $50 \%$ of dextrose (NeoNutri-Brazil), Group P received packages containing 100\% dextrose. On the fourteenth day, the subjects were asked to perform a resistance training session of five exercises (bench press, seated row, leg extension, leg curl and leg press), each in three sets of ten repetitions at 75\% of $1 \mathrm{RM}$. Approximately two minutes of rest was allowed between each exercise. Blood was collected before $\left(\mathrm{D}_{14}\right)$ exercise for $\mathrm{CK}$ analysis. Twenty-four hours later $\left(D_{15}\right)$ another blood sample was collected for CK quantification (Figure 2).

The tests and experiments were performed at the same time interval (from 2:00-5:00 pm) and the room temperature was kept at $25^{\circ} \mathrm{C}$. Due to the exercise equipment design variations, we chose to describe the exercise force as arbitrary units (AU). This procedure was utilized in an attempt to simplify matters for research purposes.

\section{Blood samples and Biochemical Analysis}

The blood sample was immediately deposited and homogenized in a heparinized tube followed by $1600 \mathrm{xg}$ centrifugation for $20 \mathrm{~min}$. The plasma was separated and treated with $50 \mathrm{mM}$ HEPES. An enzymatic method at $37^{\circ} \mathrm{C}$ was used for CK activity analysis (CK-UV NACoptimized, Biodiagnostica, Brazil). This method uses a set of coupled reactions (Figure 1) in which the CK activity is measured indirectly from the NADH concentration variation. NADH absorbance was measured on a Specord M500 spectrophotometer (Zeiss - Germany) at $340 \mathrm{~nm}$.

For assessment of creatine influence in CK detection, a plasma sample collected after a twelve-hour fasting condition was separated and creatine solution (Nutrisport - Brazil) was added. The titration curve was within the previously described creatine activity in athlete's blood after supplementation (Persky et al., 2003). The analyses were made in triplicate at different incubation times in order to obtain a linear product increase.

\section{Statistical Analysis}

The Levene test for homogeneity analysis was used.

\begin{tabular}{|l|c|c|c|c|c|c|c|c|c|c|c|}
\hline \multicolumn{1}{|c|}{ Days } & 0 & $1-6$ & 7 & 8 & 9 & 10 & 11 & 12 & 13 & 14 & 15 \\
\hline $1 \mathrm{RM}$ & $*$ & & & & & & & & & & \\
\hline $\begin{array}{l}\text { Blood Collection } \\
\text { (pre-exercise) }\end{array}$ & $*$ & & $*$ & & & & & & & $*$ & \\
\hline Exercise & & & & & & & & & & $*$ & \\
\hline $\begin{array}{l}\text { Blood Collection } \\
\text { (post-exercise) }\end{array}$ & & & & & & & & & & $*$ & $*$ \\
\hline
\end{tabular}

FIGURE 2 - Study timeline. The subjects were anthropometrically and biochemically evaluated, after which they were submitted to a $1 R M$ test $\left(\mathrm{D}_{0}\right)$. The anthropometry and biochemical evaluations were repeated on the seventh; fourteenth and fifteenth days $\left(\mathrm{D}_{7}, \mathrm{D}_{14}\right.$ and $\left.\mathrm{D}_{15}\right)$ - (A) anthropometry; (1RM) maximal repetition test. Creatine or placebo supplementation (gray shaded area). 
Two-way ANOVA was used to compare groups and different times of study protocol, and Tukey's post-hoc test was performed when appropriate. The probability level for significance was set at 0.05 . The reliability of the CK activity assessments was determined through calculation of intraclass correlation coefficients (ICC). Statistical analyses were done using the SPSS ${ }^{\circledR} 13.0$ package for Windows (LEAD Technologies, 2004).

\section{RESULTS}

To maintain the functional homogeny between the groups, we compared body mass, age, height, average diet and maximal strength (1RM). Statistical analysis revealed there were no significant differences among the groups (Table I).

In order identify any variation in CK activity caused by female hormonal fluctuations, the female group was studied separately according to their menstrual cycle phase (Luteal, Follicular and Menses Phases). No difference in CK activity measured on the days $\mathrm{D}_{0}, \mathrm{D}_{7}$ and $\mathrm{D}_{14}$ was found for members of the female group or during their cycle phases (Table II).
Also no changes were observed in the CK activity measured between $\mathrm{D}_{7}$ and $\mathrm{D}_{14}$, the period in which subjects (men and women) were supplemented with either creatine or placebo supplementation (Table III). This data suggests that the use of the supplements had no influence on CK basal levels.

The exercises resulted in an increase in CK activity of nearly $140 \%$ among the women, and $200 \%$ in the men. Supplemented women and men showed a CK activity increase on $\mathrm{D}_{15}$ (Figures 3 and 4 ), but there was no difference in CK activity between the creatine supplemented and the placebo subjects. However, the CK increase slope curve was greater in men than women $(P<0.05)$.

There was no variation in $\mathrm{CK}$ activity measured in all the groups during the two weeks prior to the exercise. After exercise, the CK activity increased approximately $100 \%$ in women and almost $300 \%$ in men but without significant differences between the groups $(P>0.05)$ (Figure 3 and 4).

In order to determine if plasma creatine concentration affects the determination of the CK by means of the Oliver-Rosalki method, we assessed the creatine dependence of the CK activity using an in vitro experiment. We

TABLE II - CK activity in women measured before the exercise program. Women were divided according to their hormonal phase and their CK activity measured. No difference in $\mathrm{CK}$ content in the distinct phases or groups was found $(P>0.05)$

\begin{tabular}{lccc}
\hline Group P & $\mathrm{D}_{0}$ & $\mathrm{D}_{7}$ & $\mathrm{D}_{14}$ \\
\hline Luteal phase $(\mathrm{n}=3)$ & $107 \pm 7$ & $92 \pm 15$ & $84 \pm 19$ \\
Follicular phase $(\mathrm{n}=5)$ & $84 \pm 35$ & $95 \pm 40$ & $89 \pm 45$ \\
Menses phase $(\mathrm{n}=3)$ & $92 \pm 53$ & $108 \pm 33$ & $84 \pm 26$ \\
Women (total) $\mathrm{P}(\mathrm{n}=11)$ & $96 \pm 36$ & $99 \pm 34$ & $86 \pm 35$ \\
\hline Group Cr & & $82 \pm 21$ & $95 \pm 30$ \\
\hline Luteal phase $(\mathrm{n}=3)$ & $92 \pm 31$ & $49 \pm 9$ & $57 \pm 6$ \\
Follicular phase $(\mathrm{n}=3)$ & $55 \pm 18$ & $85 \pm 44$ & $73 \pm 32$ \\
Menses phase $(\mathrm{n}=5)$ & $87 \pm 33$ & $73 \pm 36$ & $69 \pm 25$ \\
Women (total) $\mathrm{Cr}(\mathrm{n}=11)$ & $77 \pm 30$ & &
\end{tabular}

TABLE III - CK activity in men and women measured before exercise

\begin{tabular}{lccc}
\hline Group P & $\mathrm{D}_{0}$ & $\mathrm{D}_{7}$ & $\mathrm{D}_{14}$ \\
\hline Women P $(\mathrm{n}=11)$ & $96 \pm 36$ & $99 \pm 34$ & $86 \pm 35$ \\
Men P $(\mathrm{n}=12)$ & $125 \pm 92^{*}$ & $119 \pm 59^{*}$ & $121 \pm 102$ \\
Women Cr $(\mathrm{n}=11)$ & $77 \pm 30$ & $73 \pm 36$ & $69 \pm 25$ \\
Men Cr $(\mathrm{n}=15)$ & $128 \pm 58^{*}$ & $114 \pm 43^{*}$ & $98 \pm 68$ \\
Total women $(\mathrm{n}=22)$ & $87 \pm 33$ & $86 \pm 34$ & $81 \pm 30$ \\
Total men $(\mathrm{n}=27)$ & $127 \pm 74 \dagger$ & $116 \pm 50 \dagger$ & $109 \pm 84$ \\
\hline
\end{tabular}

$(*)$ Significant in relation to women $\mathrm{Cr}(P<0.05)$. (†) Significant between total men and total women $(P<0.05)$. 


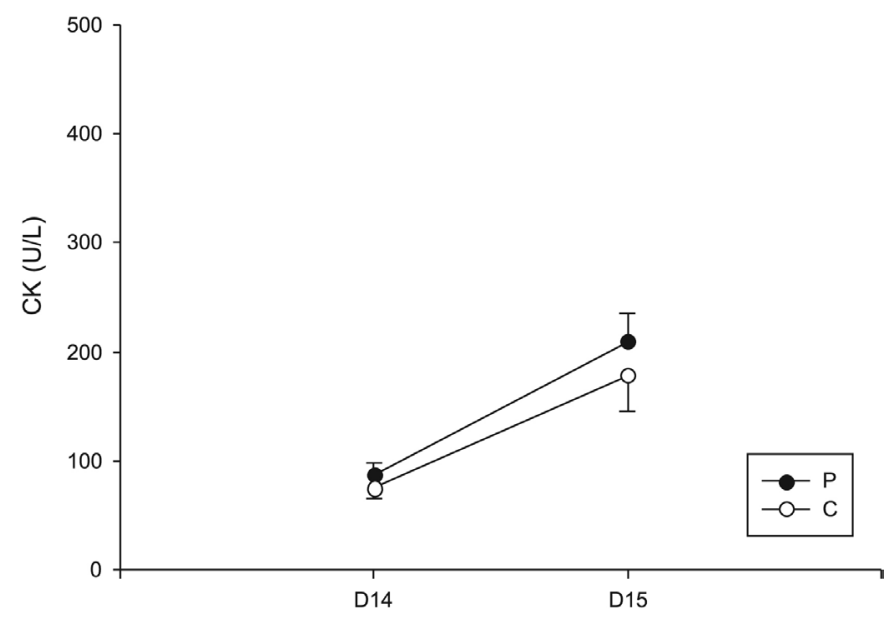

FIGURE 3 - Increase in CK activity in women after exercise. The $\mathrm{CK}$ activity increased after 24 hours of the exercise performance $(P<0.05)$. The increase was the same for creatine and placebo groups $(P>0.05)$. Values are mean $\pm \mathrm{SD}$.

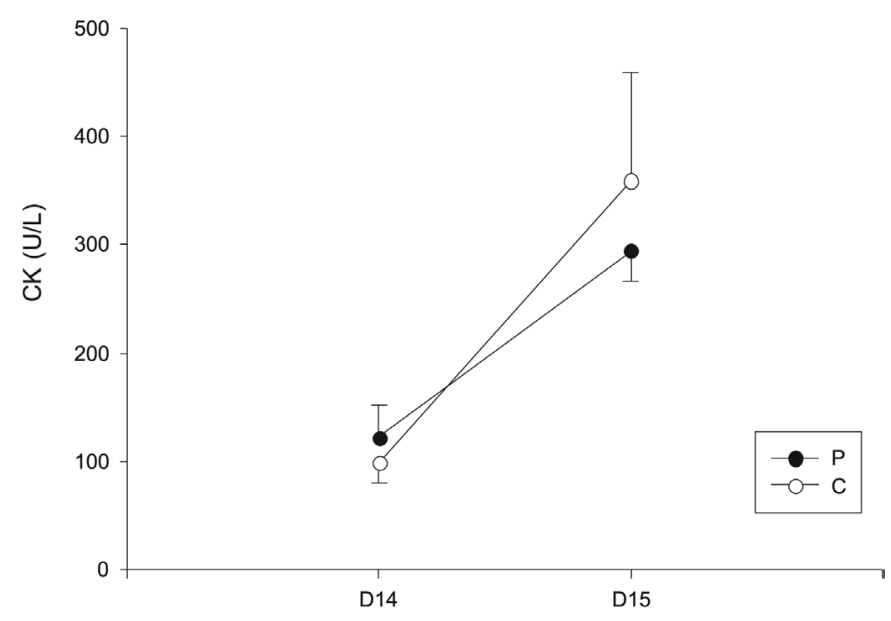

FIGURE 4 - Increase in CK activity in men after exercise. The CK activity increased after twenty-four hours of the exercise performance $(P<0.05)$, however this increase was equal for both groups $(P>0.05)$. Values are mean $\pm \mathrm{SD}$.

measured the activity of $\mathrm{CK}$ in different creatine concentrations at $37^{\circ} \mathrm{C}$. Our data showed that concentrations up to $5 \mathrm{mM}$ of creatine had no effect on the CK activity measured (Figure 5).

\section{DISCUSSION}

One of the most commonly used methods to measure creatine kinase (CK, EC 2.7.3.2) activity in blood is the analysis of its enzymatic activity (Oliver-Rosalki method). It has also been utilized in numerous exercise sciences studies, including those in which the individuals were subjected to creatine supplementation (Robinson et al., 2000; Clarkson, Hubal, 2002; Nosaka et al., 2002). The present findings clearly show that, even with concentration

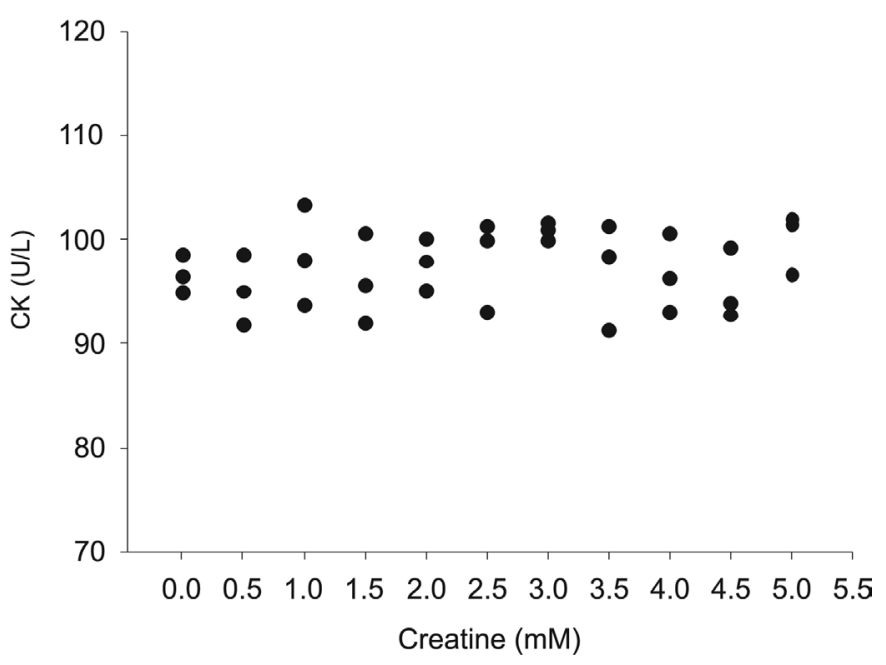

FIGURE 5 - CK activity using the Oliver-Rosalki method (Rosalki, 1967) in different blood creatine concentrations. The reliability of the CK activity assessments was determined through calculation of ICC $(r=0.99)$. No significant differences between analyses were found $(P>0.01)$. Values are mean $\pm \mathrm{SD}$.

values higher than those reached during supplementation $(5 \mathrm{mM})$, no alteration in the results obtained through the method were evident.

Our results also suggest no influences of the female menstrual cycle hormonal fluctuations in our experimental design or in the CK activity. In a previous study, BuckleyBleiler et al. (1988) found no differences in the serum CK activity post-exercise among women with different levels of estrogen. Thus, they postulated that this hormone would not behave as a protector of the muscle from injuries induced by exercise. However, Carter et al. (2001) verified a correlation between the high pre-exercise estrogen levels and low CK post-exercise activity. In their study, the exercise performed was downhill running, whereas BuckleyBleiler et al. (1988) used knee eccentric contractions, an experimental design closer to the present model.

Our study showed differences between men and women in CK activity post-exercise, contrary to the findings of Stupka et al. (2000). However, these authors utilized exercises limited to the lower limbs, in contrast to our usage of many different muscle group exercises. Rinard et al. (2000), states that there are a few differences in strength between men and women in the lower limbs; i.e. the body segment used in the experimental design of Stupka et al.. Perhaps the greater muscular demand of the more complete total body resistance work we employed allowed gender differences to manifest and be revealed.

It is well accepted that the muscle mass in men is typically greater than in women, which can lead to the possibility of muscle injury markers increasing more in men than in women. There were no differences, however, 
when comparing the percentage of CK activity increase in men and women under any of our conditions (pre- post- supplementation; pre- post- exercise). This may suggest that despite the difference between men and women in absolute values, no difference persists if values are compared in relative (percentages) terms. This reinforces the hypothesis that the differences vary depending on the amount of total muscle mass and intensity of effort.

Persky et al. (2003) measured the changes in plasma creatine concentration in supplemented individuals, showing that these can attain plasma levels of $2 \mathrm{mM}$. Due to the assay methodology involving indirect evaluation of the $\mathrm{CK}$ activity, and all the coupled reactions that are involved in the measurement, a left-ward shift on the CK reaction would be expected due to cross-reactivity. Such plasma or serum creatine concentrations could inhibit the CK activity determination, creating an artifact in the measurement technique and invalid results. We examined blood levels 2.5 times higher than this level and saw no substantial effect on the measurement of CK activity. These data are compelling evidence that the Oliver-Rosalki method (1967) for measuring CK activity is robust and sufficiently specific to avoid compromise by elevations in blood creatine levels. This assumption would appear to be true for the levels of creatine supplementation used in this study.

In conclusion, $\mathrm{CK}$ activity increases after physical activities are considered a muscle injury indicator. Our data corroborate these findings and show that creatine supplementation over a five day period neither causes differences in $\mathrm{CK}$ activity, nor significantly impacts the CK measurement methodology.

\section{ACKNOWLEDGEMENTS}

The authors are grateful to Professor Eric Rawson (Department of Exercise Science and Athletics - Bloomsburg University, USA) for stimulating discussions on creatine supplementation and exercise-induced muscle injuries.

\section{REFERENCES}

BECQUE, M. D.; LOCHMANN, J. D.; MELROSE, D. R. Effects of oral creatine supplementation on muscular strength and body composition. Med. Sci. Sports Exerc., v.32, p.654-658, 2000.

BRANCACCIO, P.; MAFFULLI, N.; LIMONGELLI, F. M. Creatine kinase monitoring in sport medicine. Br. Med. Bull., v.81-82, p.209-230, 2007.
BRUDNAK, M. A. Creatine: are the benefits worth the risk? Toxicol. Letters., v.150, p.123-130, 2004.

BUCKLEY-BLEILER, R.; MAUGHAN, R. J.; CLARKSON, P. M.; BLEILER, T. L.; WHITING, P. H. Serum creatine kinase activity after isometric exercise in premenopausal women. Exp. Aging Res., v.15, p.195-198, 1988.

CARTER, A.; DOBRIDGE, J.; HACKNEY, A. C. Influence of estrogen on markers of muscle tissue damage following eccentric exercise. Fiziol. Cheloveka (Human Physiology), v.27, p.133-137, 2001.

CHEN, T. C.; HSIEH, S. S. Effects of a 7-day eccentric training period on muscle damage and inflammation. Med. Sci. Sports Exerc., v.33, p.1732-1738, 2002.

CLARKSON, P. M.; HUBAL, M. J. Exercise-induced muscle damage in humans. Am. J. Phys. Med. Rehabil., v.81, suppl., p.S52-S69, 2002.

DENNEHY, C. E.; TSOUROUNIS, C.; HORN, A. J. Dietary supplement-related adverse events reported to the California Poison Control System. Am. J. Health-System Pharm., v.62, p.1476-1482, 2005.

HOOTMAN, J. M.; MACERA, C. A.; AINSWORTH, B. E.; ADDY, C. L.; MARTIN, M.; BLAIR, S. N. Epidemiology of musculoskeletal injuries among sedentary and physically active adults. Med. Sci. Sports Exerc., v.34, p.838-844, 2002.

KREIDER, R. B.; MELTON, C.; RASMUSSEN, C. J.; GRENWOOD, M.; LANCASTER, S.; CANTLER, E. C.; MILNOR, P.; ALMADA, A. L. Long-term Creatine supplementation does not significantly affect clinical markers of health in athletes. Mol. Cell. Biochem., v.244, p.95-104, 2003.

LEMON, P. W. R. Dietary creatine supplementation and exercise performance: why inconsistent results? Can. J. Appl. Physiol., v.27, p.663-680, 2002.

MACHADO, M.; ZOVICO, P. V. C.; SILVA, D. P.; PEREIRA, L. N.; BARRETO, J. G.; PEREIRA, R. Caffeine does not increase the resistance-exercise induced micro-damage. $J$. Exerc. Sci. Fit., v.6, p.115-120, 2008. 
MATTHEWS, R. T.; YANG, L.; JENKINS, B. G.; FERRANTE, R. J.; ROSEN, B. R.; KADDURAH-DAOUK, R.; BEAL, M. F. Neuroprotective effects of Creatine and Cyclocreatine in animal models of Huntington's disease. J. Neurosc., v.18, p.156-163, 1998.

MIHIC, S.; MACDONALD, J. R.; MACKENZIE, S.; TARNOPOLSKY, M. A. Accute creatine loading increases fat-free mass, but not affect blood pressure, plasma creatine, or CK activity in men and women. Med. Sci. Sports Exerc., v.32, p.291-296, 2000 .

NOSAKA, K.; NEWTON, M.; SACCO, P. Muscle damage and soreness after endurance exercise of the elbow flexors. Med. Sci. Sports Exerc., v.34, p.920-927, 2002.

PERSKY, A. M.; MÜLLER, M.; DARENDORF, H.; GRANT, M.; BRAZEAU, G. A.; HOCHAUS, G. Single- and multiple-dose pharmacokinetics of oral creatine. J. Clin. Pharmacol., v.43, p.29-37, 2003.

PHILLIPS, T.; CHILDS, A. C.; DREON, D. M.; PHINNEY, S.; LEEUWENBURGH, C. A Dietary supplement Attenuates IL-6 and CRP after eccentric exercise in untrained males. Med. Sci. Sports Exerc., v.35, p.2032-2037, 2003.

RAWSON, E. S.; CONTI, M. P.; MILES, M. P. Creatine supplementation does not reduce muscle damage or enhance recovery from resistance exercise. J. Strength Cond. Res., v.21, p.1208-1213, 2007.

RAWSON, E. S.; GUNN, B.; CLARKSON, P. M. The effects of creatine supplementation on exercise-induced muscle damage. J. Strength Cond. Res., v.15, p.178-184, 2001.

RAWSON, E. S.; PERSKY, A. M. Mechanisms of muscular adaptations to creatine supplementation. Int. Sport Med. J., v.8, p.43-53, 2007.
RINARD, J.; CLARKSON, P. M.; SMITH, L. L.; GROSSMAN, M. Response of males and females to high-force eccentric exercise. J. Sports Sci., v.18, p.229-236, 2000.

ROBINSON, T. M.; SEWELL, D. A.; CASEY, A.; STEENGE, G.; GREENHAFF, P. L. Dietary creatine supplementation does not affect some haematological indices, or indices of muscle damage and hepatic and renal function. Br. J. Sports Med., v.34, p.284-288, 2000.

ROSALKI, S. B. An improved procedure for serum creatine phosphokinase determination. J. Lab. Clin. Med., v.69, p.696-705, 1967.

SAKS, V. A.; STRUMIA, E. Phosphocreatine: molecular and cellular aspects of the mechanism of cardioprotective action. Curr. Ther. Res., v.53, p.565-598, 1993.

STUPKA, N.; LOWTHER, S.; CHORNEYKO, K.; BOURGEOIS, J. M.; HOGBEN, C.; TARNOPOLSKY, M. A. Gender differences in muscle inflammation after eccentric exercise. J. Appl. Physiol., v.89, p.2325-2332, 2000 .

TERJUNG, R. L.; CLARKSON, P.; EICHNER, E. R.; GREENHAFF, P. L.; HESPEL, P. J.; ISRAEL, R. G.; KRAEMER, W. J.; MEYER, R. A.; SPRIET, L. L.; TARNOPOLSKY, M. A.; WAGENMAKERS, A. J. M.; WILLIAMS, M. H. The American College of Sports medicine roundtable on the physiological and health effect of oral creatine supplementation. Med. Sci. Sports Exerc., v.32, p.706-717, 2000.

TIDBALL, J. G. Inflammatory processes in muscle injury and repair. Am. J. Physiol. Regul. Integr. Comp. Physiol., v.288, p.R345-R353, 2005.

Received for publication on $18^{\text {th }}$ September 2008. Accepted for publication on $25^{\text {th }}$ May 2009. 
